\title{
Steroidal regulation of connective tissue growth factor (CCN2; CTGF) synthesis in the mouse
} uterus

\author{
M A E Rageh, E E-D A Moussad, A K Wilson, D R Brigstock
}

\begin{abstract}
Aims-To determine mechanisms regulating the production of connective tissue growth factor (CCN2; CTGF) and transforming growth factor $\beta 1$ (TGF- $\beta 1$ ) in the mouse uterus.

Methods-In situ hybridisation and immunohistochemistry were used to localise CCN2 (CTGF) and TGF- $\beta 1$ in uteri from sexually mature female mice that had either been (1) mated with sterile males to induce pseudopregnancy or (2) ovariectomised (OVX) and administered estradiol-17 $\beta\left(E_{2}\right)$ or progesterone $\left(P_{4}\right)$, either alone or in combination. Uteri collected on days $0.5,1.5,2.5,3.5,4.5$, or 5.5 of pseudopregnancy or at one, three, six, 12 , or 24 hours after steroid administration were fixed, sectioned, and incubated with specific riboprobes or antibodies to permit detection and localisation of mRNA or protein for CTGF and TGF- $\beta 1$. Results-On days 0.5-2.5 of pseudopregnancy, CCN2 (CTGF) and TGF- $\beta 1$ were principally colocalised to uterine epithelial cells, with much smaller amounts in the stroma. On days $3.5-4.5$, there was a reduction of CCN2 (CTGF) and TGF- $\beta 1$ in the epithelium but an increase in stromal and endothelial cells, corresponding to a period of extracellular matrix remodelling and neovascularisation within the endometrium. In OVX mice, epithelial cells were weakly positive for both CCN2 (CTGF) and TGF- $\beta 1$ in the absence of steroid hormones. Epithelial CTGF mRNA production were strongly but transiently stimulated in OVX mice cells by $E_{2}$. These effects were antagonised by $\mathbf{P}_{4}$, which itself transiently stimulated epithelial CCN2 (CTGF) production, although less robustly than $E_{2}$. CTGF and TGF- $\beta 1$ protein amounts were high in epithelial cells throughout steroid treatment and were increased in the stroma, where they were relatively long lived. Stromal CCN2 (CTGF) and TGF- $\beta 1$ were lower after co-administration of $E_{2}$ and $P_{4}$ than in response to each hormone individually. Although ccn2 (ctgf) is a TGF- $\beta 1$ inducible gene in other systems, and both growth factors were often co-localised in uterine tissues in these studies, several treatment regimens resulted in high amounts of TGF- $\beta 1$ protein in stromal cells without the concomitant production of $\operatorname{ccn} 2$ (ctgf) mRNA.
\end{abstract}

Conclusions-Maternal factors are principal cues for CCN2 (CTGF) and TGF- $\beta 1$ production in the uterus because (1) their expression during pseudopregnancy is comparable to that seen in pregnancy and (2) they are regulated by ovarian steroids. TGF- $\beta$ dependent and independent mechanisms of ccn2 (ctgf) gene transcription exist in the uterus that are variably regulated by steroid hormones. Collectively, the data support a role for CCN2 (CTGF) in mediating the effects of steroid hormones and TGF- $\beta$ on endometrial function.

(F Clin Pathol: Mol Pathol 2001;54:338-346)

Keywords: CCN; reproductive tract; oestrogen; progesterone; connective tissue growth factor; uterus

Connective tissue growth factor (CCN2; CTGF) is a multifunctional mosaic protein that is a member of the CCN2 (CTGF)/CCN1 (CYR61)/CCN3 (NOV) family. ${ }^{1}$ CCN2 (CTGF) appears to be involved in diverse cellular functions such as proliferation, adhesion, migration, apoptosis, and extracellular matrix (ECM) production..$^{1-3}$ These wide ranging biological activities, together with mRNA and protein expression studies, have resulted in proposed roles for CCN2 (CTGF) in processes such as embryonic development, tissue differentiation, angiogenesis, and wound healing, in addition to various pathologies such as fibrosis, inflammation, and tumour growth. ${ }^{1}$ CCN2 (CTGF) is produced by and acts on a wide variety of cell types including fibroblasts, vascular smooth muscle cells, endothelial cells, epithelial cells, and cells of the nervous system. ${ }^{4}$ In certain cell types, ccn2 (ctgf) is transcriptionally activated by transforming growth factor $\beta$ (TGF- $\beta) .^{2-11}$ This mechanism of induction has become a central theme in accounting for certain biological actions that are shared both by CCN2 (CTGF) and TGF- $\beta$, most notably the stimulation of ECM production. ${ }^{2}{ }^{12}$ Accordingly, CCN2 (CTGF) and TGF- $\beta$ are frequently coexpressed in tissues that are undergoing ECM remodelling or synthesis, such as those that differentiate during development or exhibit pathological fibrotic transformation. Although most attention has been focused on the possible role of CCN2 (CTGF) as a downstream mediator of the activity of TGF- $\beta$ in fibrotic disorders and wound repair, it is nonetheless clear that CCN2 (CTGF) also has important roles in regulating cellular homeostasis under normal circumstances. For example, it is present in 
diverse organ systems and tissues during embryogenesis, ${ }^{13-15}$ is involved in chrondrogenesis and endochondral ossification, ${ }^{516-20}$ and occurs in the uterus and ovary of cycling and pregnant mammals. ${ }^{14}{ }^{1521-26}$

Relatively little is known about the role of CCN2 (CTGF) in the uterus or the mechanisms by which uterine ccn2 (ctgf) gene transcription is regulated. Studies in the pig have revealed that a variety of CCN2 (CTGF) isoforms, ranging from $10 \mathrm{kDa}$ to $38 \mathrm{kDa}$, are present in uterine fluids that exhibit cyclic and pregnancy associated changes in their concentrations. ${ }^{24-26}$ Low mass CCN2 (CTGF) molecules correspond principally to one or two structural modules located at the C-terminus of the primary translational product and arise through limited proteolysis of full length $38 \mathrm{kDa}$ CCN2 (CTGF). ${ }^{24}$ A variety of CCN2 (CTGF) isoforms have also been identified in mouse uterine fluids. ${ }^{14}$ In the cycling mouse, CCN2 (CTGF) was localised mainly in luminal and glandular epithelial cells in which the signal is somewhat attenuated at the time of oestrus. ${ }^{14}$ CCN2 (CTGF) localisation in pregnant animals mimicked that in cycling animals until day 4.5, when the blastocyst was first detected in the uterine lumen. At this time, epithelial expression of CCN2 (CTGF) was substantially reduced and followed by high expression in decidual cells after invasion and implantation by the embryo. ${ }^{14}$ Collectively, these data suggest that in the mouse uterus, CCN2 (CTGF) is physiologically important in epithelial cells during the oestrous cycle and in differentiating stromal cells during early pregnancy. Similar observations have been made in women, where it was shown that epithelial cells and decidua expressed relatively high amounts of CCN2 (CTGF) compared with other cell types. ${ }^{21}$ Although the pig does not exhibit a classic decidual cell reaction, epithelial cells are a major site of CCN2 (CTGF) synthesis, but have transiently reduced CTGF during the peri-attachment period, coincident with stromal ECM remodelling and neovascularisation. ${ }^{4}$ In all three species (pig, mouse, human), CTGF expression has been documented in other cell types such as endothelial cells, vascular smooth muscle cells and, to a much lesser extent, stromal cells. ${ }^{4121}$ These observations suggest that uterine CCN2 (CTGF) may control a variety of diverse biological processes that are delicately integrated in time and space by steroid dependent and independent mechanisms. Thus, the purpose of these studies was to determine whether the expression of CCN2 (CTGF) is embryo or steroid dependent and to define the extent to which CCN2 (CTGF) expression mimics that of TGF- $\beta$.

\section{Materials and methods}

MATERIALS

Histochoice was obtained from Amresco (Solon, Ohio, USA). Superfrost Plus slides, Crystalmount, and Permount were from Fisher Scientific (Pittsburgh, Pennsylvania, USA). Phosphate buffered saline (PBS) was obtained from Gibco BRL (Gaithersburg, Maryland, USA). Plasmid pCRII was from Invitrogen
Corp (Carlsbad, California, USA). Normal rabbit IgG was from Vector Laboratories (Burlingame, California, USA). Power Block ${ }^{\mathrm{TM}}$ and StrAviGen Multilink kit were purchased from BioGenex (San Ramon, California, USA). Haematoxylin was obtained from Newcomer Supply (Middleton, Wisconsin, USA). Digoxygenin RNA labelling kit and sheep antidigoxygenin-alkaline phosphatase were from Roche Molecular Diagnostics (Indianapolis, Indiana, USA). NBT/BCIP chromogenic substrates were from Promega Corp (Madison Wisconsin, USA). Other chemicals were from Sigma Chemical Co (St Louis, Missouri, USA)

CCN2 (CTGF) antiserum raised in rabbits against residues $80-93$ of mouse CCN2 (CTGF) (a peptide region that is not shared with other CCN proteins) was produced and affinity purified as described previously. ${ }^{14} 1527$ Affinity purified rabbit anti-TGF- $\beta 1$ antiserum was obtained from Santa Cruz Biotechnology (Santa Cruz, California, USA). A cDNA corresponding to nucleotides -1 to 1046 of the published mouse ccn2 (fisp-12) sequence ${ }^{28}$ was generated from mRNA from TGF- $\beta 1$ stimulated mouse 3T3 cells via the reverse transcription polymerase chain reaction (RT-PCR) using the primers 5'-gcagggatccatgctcgcctc cgtcgca-3' and 5'-ccagcggccgcgaattcttacgccat gtctcc-3'. The same RNA was also used to amplify a $460 \mathrm{bp}$ murine TGF- $\beta 1 \mathrm{cDNA}$ using the primers 5 '-ccggctcctgtccaaactaaggctcgc-3' and 5'-cctctagaccagtgacgtcaaaagacagcc-3'. The amplified products from each reaction were cloned into pCRII and the resulting pCRII/ $\operatorname{ccn} 2$ (ctgf) or pCRII/TGF- $\beta 1$ plasmids were cut with diagnostic restriction enzymes to verify insert directionality. Digoxygenin-UTP labelled RNA sense and antisense probes were made using a digoxygenin RNA labelling kit, according to the manufacturer's instructions. $\mathrm{pCRII} / \mathrm{ccn} 2$ (ctgf) and pCRII/TGF- $\beta 1$ were linearised with EcoRV for SP6 generation of the sense probe and with Kpn I for T7 generation of the antisense probe.

ANIMALS

Swiss Webster mice (Harlan Sprague Dawley, Indianapolis, Indiana, USA) were used for all experiments, which were approved by the institutional animal use and care committee of the Children's Research Institute.

\section{Pseudopregnancy}

Adult male mice were vasectomised and kept for 35 days to clear all viable sperm from the genital tract. Mating was induced between these sterile males and fertile female mice in the evening and mating was verified at $8.00 \mathrm{am}$ on the morning of the next day by the appearance of the vaginal plug. This time point was defined as day 0.5 of pseudopregnancy. The uteri of pseudopregnant females were harvested daily at 8.00 am between days 0.5 and 5.5 ( $n=3 /$ time point), the last time point being the probable day of return of oestrus.

\section{Steroid hormone treatment}

Adult virgin female mice were ovariectomised (OVX) and kept for two weeks to deplete them 
of circulating ovarian steroids. On day 15 postovariectomy, animals were given a single subcutaneous injection of either estradiol-17 $\beta\left(\mathrm{E}_{2}\right)$ (250 ng), progesterone $\left(\mathbf{P}_{4}\right)(2 \mathrm{mg})$, or a combination of both hormones in $200 \mu \mathrm{l}$ sesame oil ( $\mathrm{n}=3 /$ treatment group). OVX animals that received $200 \mu \mathrm{l}$ sesame oil only were used as negative controls. The uteri of steroid injected animals or oil injected controls were collected one, three, six, 12, and 24 hours after injection.

TISSUE PROCESSING

Mice were humanely sacrificed at the designated times and the uteri were removed by dissection. Uteri were fixed in Histochoice for 24 hours and kept in $70 \%$ ethanol at $4^{\circ} \mathrm{C}$ until use. Paraffin wax embedded sections ( $5 \mu \mathrm{m}$ thick) were cut using a microtome and placed on Superfrost Plus slides, which were then heated at $60^{\circ} \mathrm{C}$ for one to two hours and dewaxed in xylene for five minutes. Sections were then hydrated through a series of graded ethanol washes (95\%, 90\%, $70 \%$, and $50 \%$ ethanol) and then placed in distilled water for a few minutes.

IMMUNOHISTOCHEMISTRY FOR CCN2 (CTGF) AND TGF- $\beta 1$

Endogenous peroxidase activity was blocked by placing slides in $3 \% \mathrm{H}_{2} \mathrm{O}_{2}$ for 15 minutes, after which they were rinsed in distilled water followed by PBS. Slides were then incubated in Power Block for up to 10 minutes to block non-specific binding sites, and then rinsed with PBS for 10 minutes. Details for CCN2 (CTGF) immunohistochemistry were as described previously, ${ }^{14}{ }^{15}$ with some modifications. Sections were incubated for one hour at room temperature with $\mathrm{PBS} / 2 \%$ bovine serum albumin (BSA) containing either $10 \mu \mathrm{g} / \mathrm{ml}$ anti-CTGF IgG, $2 \mu \mathrm{g} / \mathrm{ml}$ anti-TGF- $\beta 1 \mathrm{IgG}$, or equivalent concentrations of preimmune rabbit IgG (obtained before immunisation with the CCN2 (CTGF) (81-94) peptide) or nonimmune rabbit IgG. Slides were rinsed in PBS for 10 minutes, incubated with a 1/50 dilution of Multilink biotinylated secondary antibody in $\mathrm{PBS} / 2 \%$ BSA for 20 minutes, washed in PBS for 10 minutes, and then incubated with a $1 / 50$ dilution of concentrated strepatividin conjugated peroxidase for 20 minutes. Slides were washed for 10 minutes and developed with diaminobenzidine for three minutes, after which the chromogenic colour reaction was stopped using distilled water. Slides were counterstained using haematoxylin, washed in distilled water, dehydrated, and mounted.

IN SITU HYBRIDISATION FOR CCN2 (CTGF) OR TGF- $\beta 1$

Prehybridisation was carried out by successive incubations in water, PBS, PBS/100mM glycine, PBS $/ 0.3 \%$ Triton X-100, PBS, and Tris/EDTA (TE) buffer containing $20 \mu \mathrm{g} / \mathrm{ml}$ proteinase $\mathrm{K}$. All solutions were treated with diethlpyrocarbonate. Sections were postfixed in $\mathrm{PBS} / 4 \%$ paraformaldehyde at $4^{\circ} \mathrm{C}$, washed with PBS, incubated with $0.1 \mathrm{M}$ triethanolamine buffer ( $\mathrm{pH} 8.0$ ) containing $0.25 \%$ (vol/vol) acetic acid, followed by prehybridisation buffer ( $4 \times$ saline sodium citrate (SSC) containing $50 \%$ vol $/ \mathrm{vol}$ deionised formamide) at $37^{\circ} \mathrm{C}$. Slides were then incubated with $300 \mathrm{ng} / \mathrm{ml}$ digoxygenin labelled sense or antisense ccn 2 (ctgf) or TGF- $\beta 1$ RNA probes in $300 \mu$ l hybridisation buffer $(4 \times$ SSC containing $10 \%$ dextran sulphate, $40 \%$ deionised formamide, $1 \times$ Denhardt's, $10 \mathrm{mM}$ dithiothreitol (DTT), $1 \mathrm{mg} / \mathrm{ml}$ yeast tRNA, and $1 \mathrm{mg} / \mathrm{ml}$ denatured and sheared salmon sperm DNA). Sections were incubated at $42^{\circ} \mathrm{C}$ overnight in a humid chamber. Posthybridisation steps were $2 \times$ SSC for 10 minutes at room temperature, two 15 minute washes with $2 \times \mathrm{SSC}$ at $37^{\circ} \mathrm{C}$, two 15 minute washes with $1 \times \mathrm{SSC}$ at $37^{\circ} \mathrm{C}$, two 30 minute washes with $0.1 \times \mathrm{SSC}$ at $37^{\circ} \mathrm{C}$, two 10 minute washes with buffer $1(100 \mathrm{mM}$ Tris $\mathrm{HCl} / 150 \mathrm{mM} \mathrm{NaCl}, \mathrm{pH} 7.5$ ), and a 30 minute incubation with blocking solution (buffer 1 containing $0.1 \%$ Triton X-100/2\% goat serum). Sections were then incubated for two hours with PBS $/ 0.1 \%$ Triton X-100/1\% goat serum containing a $1 / 750$ dilution of sheep antidigoxygenin-alkaline phosphatase. Sections were washed with buffer 1 and buffer $2(100 \mathrm{mM}$ Tris $\mathrm{HCl} / 100 \mathrm{mM} \mathrm{NaCl} / 50 \mathrm{mM}$ $\mathrm{MgCl}_{2}, \mathrm{pH}$ 9.5) and developed with NBT/ BCIP chromogenic substrate. The reaction was stopped using $10 \mathrm{mM}$ Tris $\mathrm{HCl}(\mathrm{pH} 8.1)$ containing $1 \mathrm{mM}$ EDTA. Slides were washed in water, counterstained with nuclear fast red, and mounted with crystal mount.

\section{Results}

In all experiments, verification that the immunohistochemical signal was specific for each protein was achieved through the use of non-immune controls (data not shown). Similarly, sense mRNA in situ hybridisation performed on all control and treatment groups was used to confirm the specificity of staining (data not shown).

PSEUDOPREGNANCY

Both ccn 2 (ctgf) and TGF- $\beta 1$ were transcribed and translated in the uteri of pseudopregnant mice (fig 1). On days $0.5-2.5$ of pseudopregnancy, strong immunohistochemical staining for CCN2 (CTGF) and TGF- $\beta 1$ was seen in the cytoplasm of the columnar luminal and glandular cells, whereas moderate to weak staining was present in the condensed aggregates of the stromal fibroblasts (fig 1). In addition, the smooth muscle fibres of the myometrium exhibited moderate CCN2 (CTGF) protein expression (data not shown). Over the same period, large amounts of ccn2 (ctgf) and TGF- $\beta 1$ mRNA were also colocalised in luminal and glandular epithelial cells, and smaller amounts were found in the underlying stroma. On days $3.5-4.5, \mathrm{ccn} 2$ (ctgf) and TGF- $\beta_{1}$ mRNA and protein values were decreased in epithelial cells but increased in stromal fibroblasts. This corresponded to stromal ECM remodelling and massive invasion of blood capillaries, which were also positive for ccn2 (ctgf) expression. By the next day (day 5.5; corresponding to the probable return of oestrus), both ccn 2 (ctgf) and TGF- $\beta 1$ protein and mRNA expression increased in the luminal and 


\section{CTGF}

\section{TGF- $\beta$}

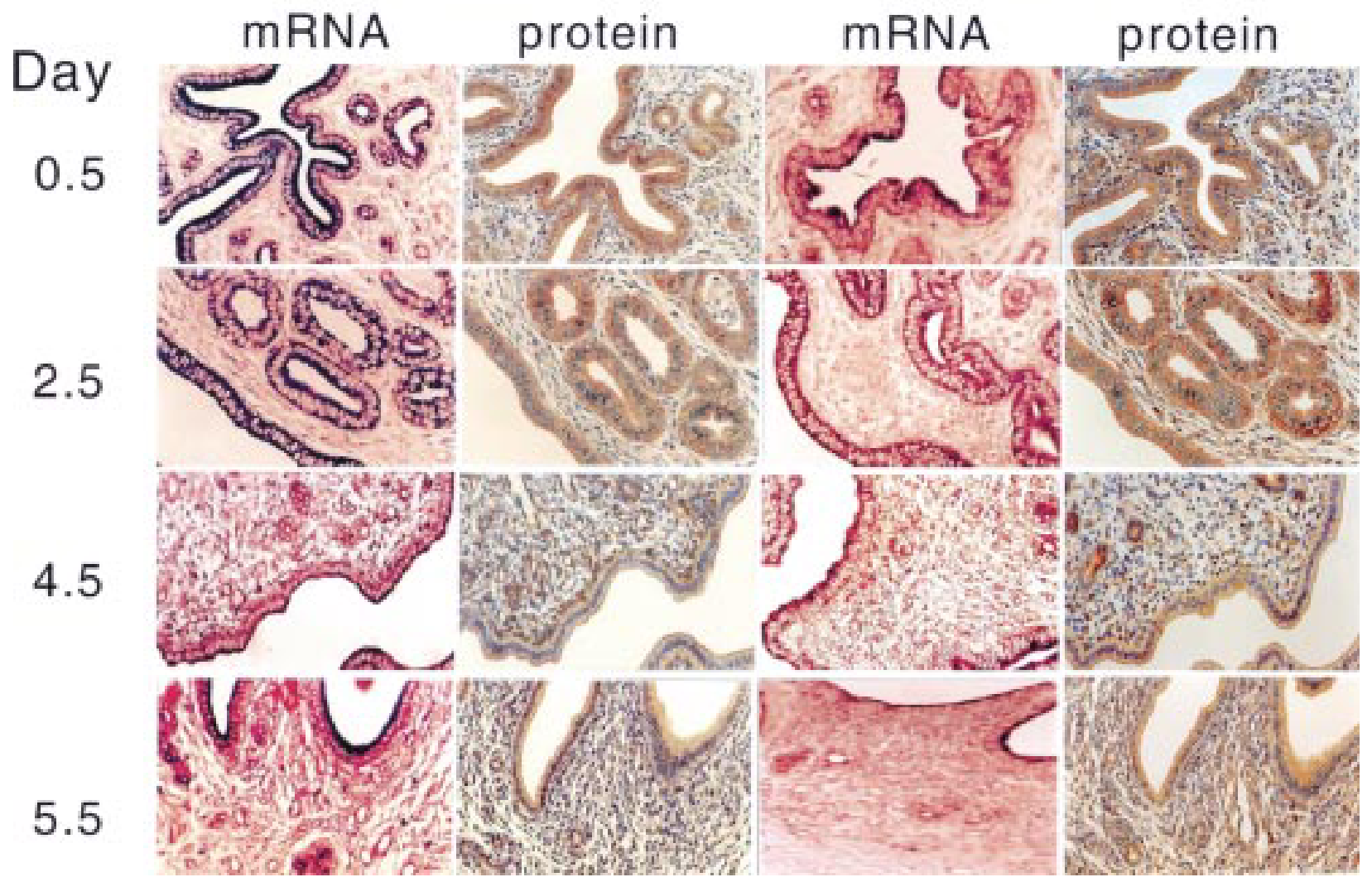

Figure 1 Uterine ccn2 (ctgf) and transforming growth factor $\beta$ (TGF- $\beta$ ) in pseudopregnant mice. Female Swiss Webster mice were mated with vasectomised males and uterine ccn2 (ctgf) and TGF- $\beta m R N A$ and protein were assessed on the indicated days of pseudopregnancy by in situ hybridisation or immmunohistochemistry, respectively.

glandular epithelial cells and was apically localised within the cells. Stromal staining for ccn2 (ctgf) or TGF- $\beta 1 \mathrm{mRNA}$ was quite low, whereas their respective protein values were relatively high.

Based on our previously published data, ${ }^{14}$ the cellular distribution of $\operatorname{con} 2$ (ctgf) in uterine tissues of pseudopregnant mice was generally comparable to that found in preimplantation pregnancy. These data suggest that during the preimplantation period, ccn2 (ctgf) expression is predominantly regulated by maternal factors. Although embryonic signals may influence ccn2 (ctgf) expression during the periimplantation or postimplantation period, these and previously published data suggested that maternal factors, such as steroid hormones, drive uterine ccn2 (ctgf) expression in cycling or early pregnant mice. To investigate this question, we next evaluated ccn2 (ctgf) and TGF- $\beta 1$ expression in the uteri of OVX mice that had been treated with acute administration of $E_{2}$ or $\mathrm{P}_{4}$, either alone or in combination.

STEROID HORMONE EFFECTS

Because the steroidal regulation of $\mathrm{mRNA}$ and protein for TGF- $\beta 1$, TGF- $\beta 2$, and TGF- $\beta 3$ in the mouse uterus has been well established from previous work, ${ }^{29}{ }^{30}$ we focused our investigation on the effects of $\mathrm{E}_{2}$ and $\mathrm{P}_{4}$ on the TGF- $\beta 1$ protein and performed this in conjunction with a comprehensive analysis of $\operatorname{ccn} 2$ (ctgf) mRNA and protein.

\section{Epithelial cells}

Two weeks postovariectomy there was a massive reduction in the overall uterine size, a decrease in the height of the luminal and glandular epithelial cells, and invasion of blood capillaries perforating the stroma (fig $2 \mathrm{~A}$ ). This phenotype was associated with greatly reduced expression of ccn2 (ctgf) mRNA, especially in epithelial cells, which normally show a very strong $\operatorname{ccn} 2$ (ctgf) mRNA signal in cycling animals (fig 1; and data not shown ${ }^{14}$ ). In control OVX animals, the low basal expression of ccn2 (ctgf) mRNA remained unaltered for up to 24 hours after oil administration, and was confined to the apical region of the cells (fig 2A). However, despite their reduced ccn2 (ctgf) mRNA expression, the amount of CCN2 (CTGF) protein detected immunohistochemically in these cells was moderately high, as was TGF- $\beta 1$. Both CCN2 (CTGF) and TGF- $\beta 1$ were distributed throughout the cell and their values were not altered in response to oil treatment at any of the time points examined (fig $2 \mathrm{~A}$ ). Thus, whereas steroid deprivation for two weeks after OVX resulted in a significant reduction of $\operatorname{ccn} 2$ (ctgf) mRNA expression in epithelial cells, compared with cycling or pseudopregnant animals, both CCN2 (CTGF) and TGF- $\beta 1$ proteins were quite stable and readily detectable.

Treatment of OVX animals with $\mathrm{E}_{2}$ (fig 2B) resulted in a dramatic but transient increase in the $\operatorname{ccn} 2$ (ctgf) mRNA and protein in uterine epithelial cells, which was detectable within one 
hour, had peaked by six hours, and had subsided by 24 hours (fig 2B). During the induction phase (one to six hours), ccn2 (ctgf) mRNA was localised throughout the epithelial cells, whereas during the attenuation phase ( 24 hours), it was confined to the apical region of the cells and resembled the localisation seen in control uteri. Greatly increased epithelial CCN2 (CTGF) and
TGF- $\beta 1$ protein expression was seen at one to 24 hours after $\mathrm{E}_{2}$ treatment (fig 2B). $\mathrm{P}_{4}$ treatment of OVX animals resulted in stimulation of $\operatorname{ccn} 2$ (ctgf) mRNA within one hour in epithelial cells, which was distributed throughout the entire cytoplasm (fig 3A). However, this induction was less robust than that stimulated by $\mathrm{E}_{2}$, and by six to 24 hours of $\mathrm{P}_{4}$ treatment,

\section{Treatment time (hours)}

A
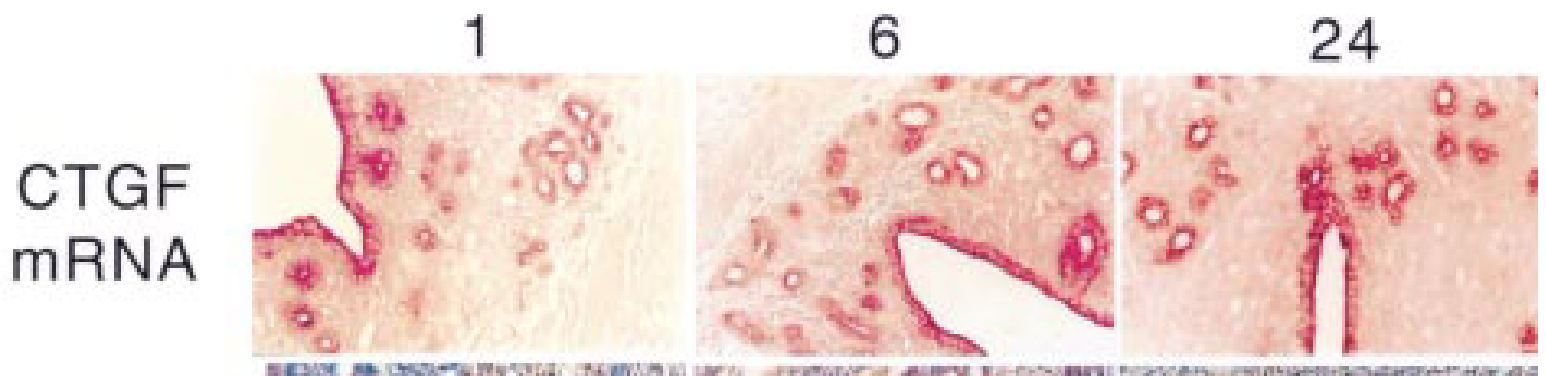

\section{CTGF protein}

\section{TGF- $\beta$ protein}

B

\section{CTGF mRNA}
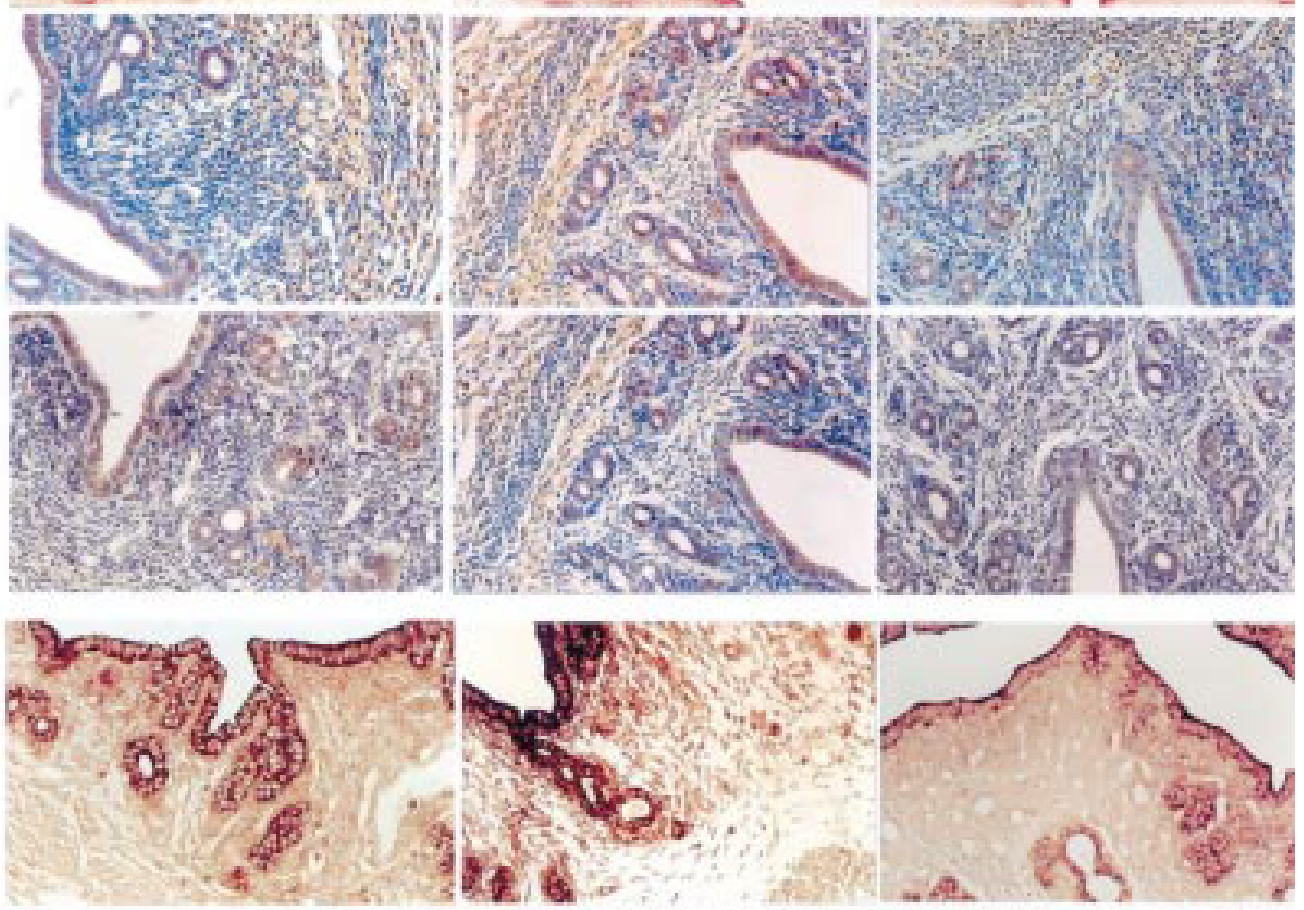

\section{CTGF protein}

\section{TGF- $\beta$ protein}

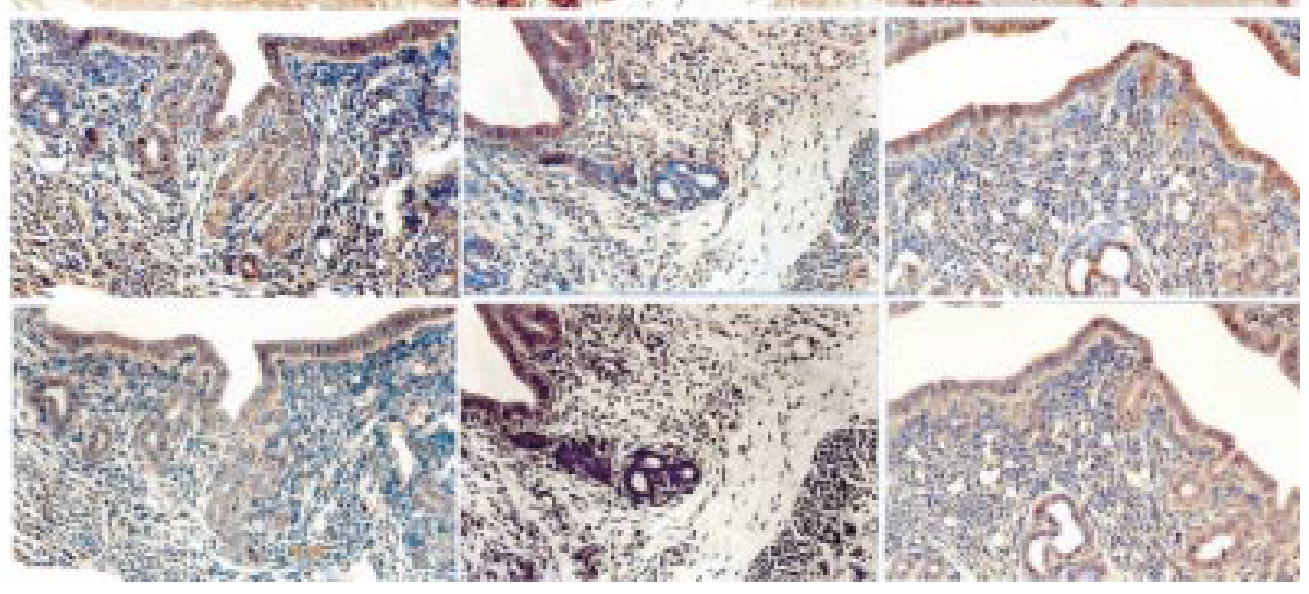

Figure 2 Steroidal regulation of uterine ccn2 (ctgf) and transforming growth factor $\beta$. Ovariectomised mice were treated with (A) sesame oil control or (B) estradiol-17 $\beta$ for the indicated amounts of time (1-24 hours). The presence of uterine ccn2 (ctgf) and TGF- $\beta$ was determined by the situ hybridisation or immunohistochemistry. 
ccn2 (ctgf) mRNA expression had declined and was confined to the apical regions of the cells. However, these changes were not parallelled by $\operatorname{ccn} 2$ (ctgf) or TGF- $\beta 1$ proteins, which remained at a constant moderate value (comparable to epithelial cells of control (oil treated)
OVX uteri) over the entire time course (fig 3A). The high amounts of ccn2 (ctgf) mRNA induced by $\mathrm{E}_{2}$ alone at one to six hours or $\mathrm{P}_{4}$ alone at one hour were absent in animals receiving both hormones at the same time (fig 3B). Nonetheless, at one to six hours, ccn2 (ctgf)

\section{Treatment time (hours)}

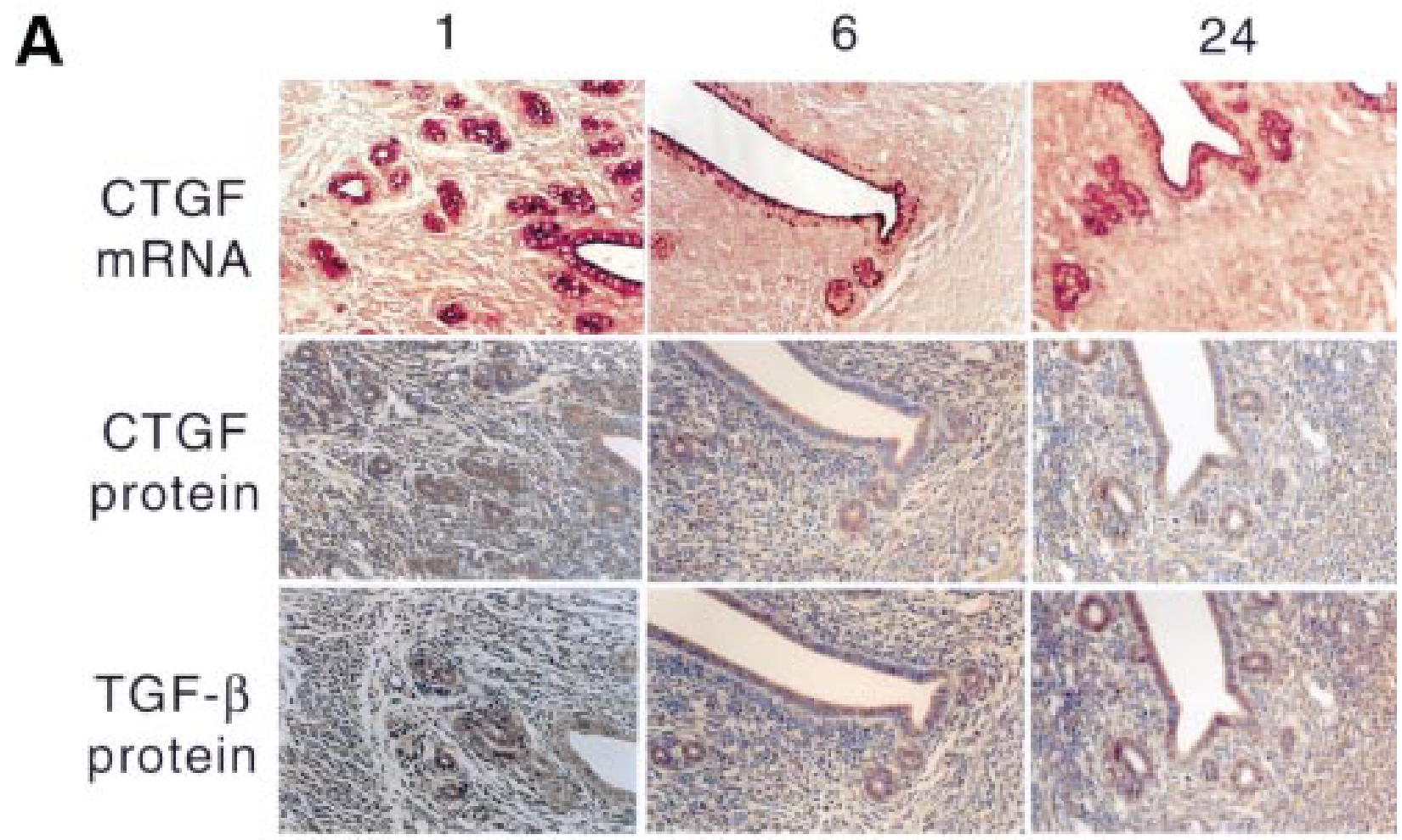

B

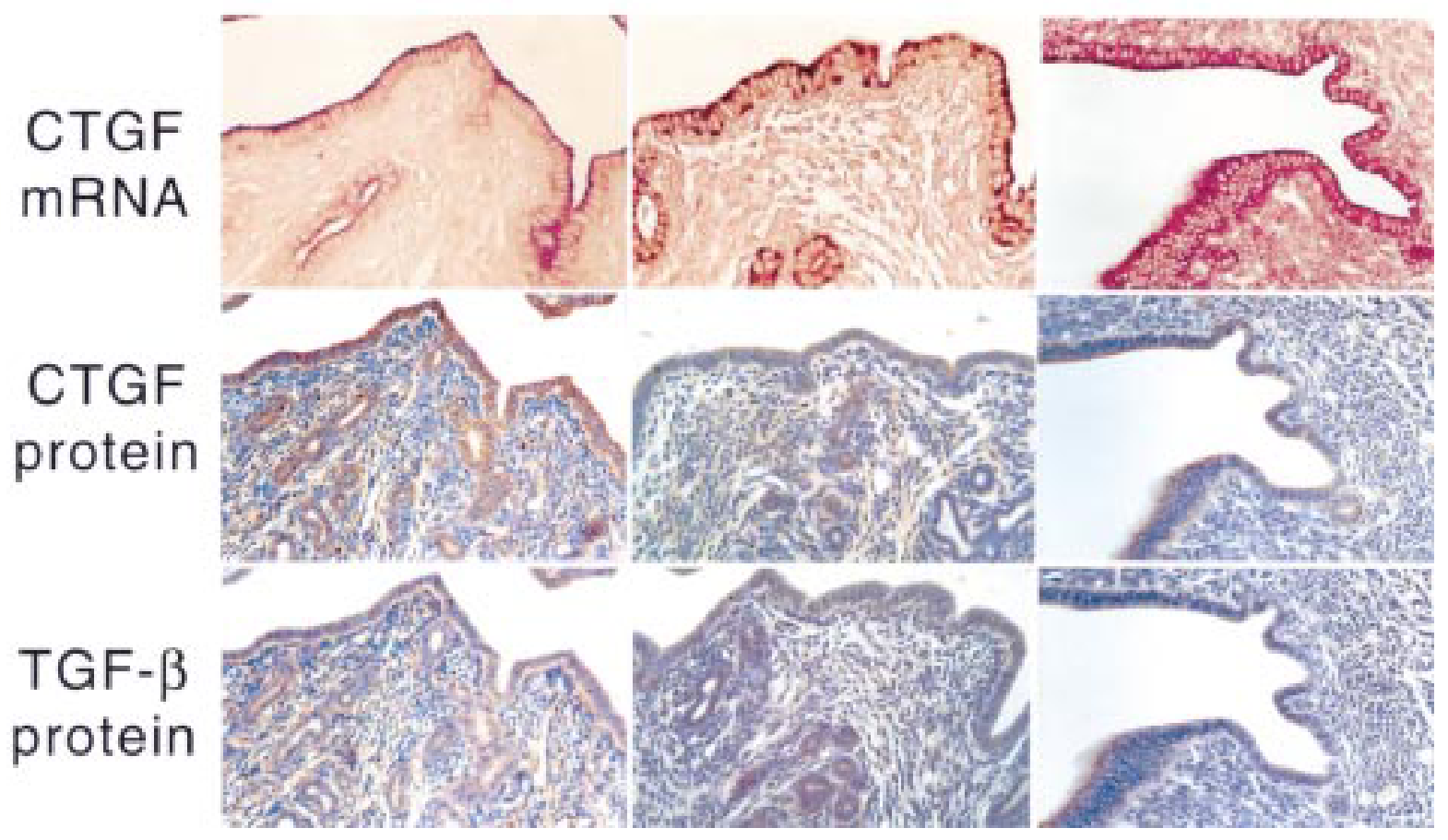

Figure 3 Steroidal regulation of uterine ccn2 (ctgf) and transforming growth factor $\beta$ (TGF- $\beta$ ). Ovariectomised mice were treated with (A) progesterone or (B) estradiol-17 $\beta$ and progesterone for the indicated amounts of time (1-24 hours). The presence of uterine ccn 2 (ctgf) and TGF- $\beta$ were determined by in situ hybridisation or immmunohistochemistry. 
mRNA was slightly higher in OVX animals receiving $\mathrm{E}_{2}$ and $\mathrm{P}_{4}$ than in OVX animals receiving the oil control. This signal was mainly apical and its intensity declined to that seen in the oil treated controls by 24 hours.

STROMAL CELLS

ccn2 (ctgf) mRNA was not detectable in the stromal fibroblasts of OVX animals for one to 24 hours after the administration of the oil control. Accordingly, low amounts of CCN2 (CTGF) and TGF- $\beta 1$ proteins were found in the stroma-lower than that seen in the myometrium (fig $2 \mathrm{~A}$ ). After $\mathrm{E}_{2}$ treatment, there was a slight increase in ccn2 (ctgf) mRNA in a few scattered stromal cells by six hours after treatment, but this increase was far less than that seen in the epithelium. Nonetheless, stromal staining for CCN2 (CTGF) and TGF- $\beta 1$ proteins was higher than in oil treated controls, and appeared to increase modestly with time. $\mathrm{P}_{4}$ did not appear to stimulate $\mathrm{ccn} 2$ (ctgf) mRNA production in the stroma, although relatively high amounts of CCN2 (CTGF) and TGF- $\beta 1$ protein were present at all time points (fig 3A). No stromal staining for ccn2 (ctgf) mRNA was present in animals receiving both $\mathrm{E}_{2}$ and $\mathrm{P}_{4}$, and the CCN2 (CTGF) and TGF- $\beta 1$ protein values were much reduced compared with the increases seen in the stroma in response to each hormone individually (fig 3B).

\section{Discussion}

The uterus is an intriguing and unique example of an organ system in which tissue turnover is cyclical and regulated primarily by steroid hormones. It is now evident that the cyclic changes in uterine cell organisation are attributable, at least in part, to the regulation by $\mathrm{E}_{2}$ and/or $\mathrm{P}_{4}$ of the synthesis of uterine polypeptide growth factors and their signal transducing receptors. ${ }^{31}$ Through the integrated action of numerous steroidally regulated molecules, including growth factors and receptors, endometrial cells undergo proliferation, differentiation, ECM remodelling, and regression..$^{32}$ In addition, during pregnancy, endometrial stromal cells are transformed to decidual cells under the influence of $\mathrm{E}_{2}$ and $\mathrm{P}_{4}$, a process that also involves changes in growth factor expression. Apart from decidualisation, uterine growth factors are also implicated in other processes during pregnancy, such as embryo-uterine signalling, placental development, and angiogenesis. ${ }^{32-34}$ Synchrony between the hormonal status of the uterus and its receptiveness for an appropriately developed blastocyst is central to successful implantation in many mammalian species. ${ }^{35-38}$ This highlights the pivotal role that steroidally regulated growth factors are likely to play in the embryomaternal interactions that enable successful establishment and maintenance of pregnancy. ${ }^{32-34} 39$ Our data establish for the first time that maternal sex steroids, including $\mathrm{E}_{2}$ and $\mathrm{P}_{4}$, are among the maternal factors that can regulate the expression of $\operatorname{ccn} 2$ (ctgf) in the uterus, suggesting that CCN2 (CTGF) probably mediates some of the growth and differentiation processes in uterine tissues that are steroid dependent. Although steroidal regulation of $\operatorname{ccn} 2$ (ctgf) has not been reported previously, our data are consistent with an earlier subtractive cDNA library strategy, which showed that the CCN2 (CTGF) related molecule CCN1 (CYR61) was induced in ovariectomised rat uteri after four hours of treatment with 17 - $\alpha$-ethynyl estradiol. ${ }^{40}$

Our experiments revealed several features regarding the regulation of $\operatorname{ccn} 2$ (ctgf) in the mouse uterus. Interestingly, the only scenarios in which uterine stromal or connective tissue cells produce large amounts of CCN2 (CTGF) are during the $\mathrm{P}_{4}$ dominated decidualisation phase of pregnancy, after $\mathrm{P}_{4}$ administration, or during periods of neovascularisation and ECM remodelling during pseudopregnancy. ${ }^{14}$ In contrast, one of the most striking features of these and previous ${ }^{14}$ data is that epithelial cells in cycling, early pregnant, or pseudopregnant animals are the principal site of uterine CCN2 (CTGF) synthesis. These data suggest that CCN2 (CTGF) may influence uterine function through its action on epithelial cells, directly or by paracrine effects on the underlying stroma. CCN2 (CTGF) is produced by a variety of epithelial cell types and regulates functional properties including adhesion, ${ }^{13}$ differentiation, ${ }^{41}{ }^{42}$ and apoptosis. ${ }^{43}$ Although direct effects of CCN2 (CTGF) on uterine epithelial cells have yet to be examined, our results also support the possibility that $\mathrm{CCN} 2$ (CTGF) is translocated from the epithelium to the stroma, as has been suggested previously for TGF- $\beta{ }^{44}$ Evidence for diffusion of CCN2 (CTGF) from its site of synthesis is shown by the presence of large amounts of CCN2 (CTGF) protein in both epithelial and stromal cells under conditions in which only the epithelial cells contain appreciable amounts of ccn2 (ctgf) mRNA (for example, on days 0.52.5 of pseudopregnancy or in control or hormone treated OVX animals). Thus, CCN2 (CTGF) may be one of the mediators of epithelial-mesenchymal cell interactions that drive uterine differentiation and support the establishment and maintenance of pregnancy.

The pseudopregnancy experiments allowed us to investigate which of the pregnancy associated changes in CCN2 (CTGF) production are independent of the presence of an activated blastocyst. The data clearly show that most of the preimplantation changes in CCN2 (CTGF) production that we reported previously $^{14}$ are embryo independent and, thus, maternally regulated. Similarly, previous studies have shown that the uterine expression of TGF- $\beta 1$, TGF- $\beta 2$, and TGF- $\beta 3$ appears to be independent of blastocyst regulation. ${ }^{29} 44$ Moreover, the pattern of CCN2 (CTGF) production that we found was comparable to that of TGF- $\beta 1$ and was principally epithelial over the first three days of pseudopregnancy. In view of previous studies supporting TGF- $\beta$ dependent $\operatorname{ccn} 2$ (ctgf) gene induction in various cell types, including epithelial cells, a functional relation between TGF- $\beta$ and CCN2 (CTGF) 
in the uterine epithelium is plausible. In addition, a striking decrease in epithelial CCN2 (CTGF) values was observed on day 4.5 in both pregnant ${ }^{14}$ and pseudopregnant (our present data) mice. This time is the normal day of implantation and is marked by extensive stromal remodelling and angiogenesis. Suppression of epithelial CCN2 (CTGF) production may allow for a net degradation of stromal ECM as an essential prerequisite to ECM remodelling and neovascularisation. In addition, the presence of CCN2 (CTGF) in the endothelial cells of the new vessels is consistent with the proposed role for CCN2 (CTGF) in regulating endothelial cell proliferation, adhesion, and survival.

The presence of $\operatorname{ccn} 2$ (ctgf) mRNA or protein or TGF- $\beta 1$ protein was not completely abolished within the two week period after ovariectomy. Similarly, the mRNA encoding TGF- $\beta 1-3$ was expressed at high basal values in the uterus of immature mice ${ }^{30}$ and TGF- $\beta 2$ or TGF- $\beta 3$ mRNA persisted in the uteri of adult ovariectomised mice. ${ }^{29}$ These data show that transcriptional activation of the uterine $\operatorname{ccn} 2$ (ctgf) and TGF- $\beta$ genes are, at least partly, steroid independent. Nonetheless, our data show that both CCN2 (CTGF) and TGF- $\beta 1$ are individually induced by $\mathrm{E}_{2}$ and $\mathrm{P}_{4}$, although the effects of each hormone are quite different. In response to a single dose of $\mathrm{E}_{2}$, $\operatorname{ccn} 2$ (ctgf) mRNA was induced in epithelial cells within one hour, peaked at six hours, and declined by 24 hours. Previous studies of the mouse uterus showed that diethylstilbestrol transiently upregulated TGF- $\beta 1$ and TGF- $\beta 2$ mRNA by three hours and TGF- $\beta 3$ mRNA within 30 minutes, with subsequent decreases to basal values by six hours. ${ }^{30}$ In another study, $\mathrm{E}_{2}$ caused a rapid (six hour) but transient induction of TGF- $\beta 2 \mathrm{mRNA}$, whereas there was no significant effect of the hormone on TGF- $\beta 3$ mRNA in mouse uteri. ${ }^{29}$ In situ hybridisation localised the mRNAs for all three TGF- $\beta$ isoforms primarily to the uterine epithelium. ${ }^{29}{ }^{30}$ Unlike the transient nature of TGF- $\beta$ mRNA induction elicited by $\mathrm{E}_{2}$, the TGF- $\beta$ proteins persisted in the epithelium for a relatively long time. ${ }^{30}$ Following $\mathrm{E}_{2}$ stimulation, we found that CCN2 (CTGF) and TGF- $\beta 1$ proteins were long lived in both the epithelium and stroma, and were thus more broadly distributed than would be predicted from their mRNA, which was localised primarily to epithelial cells. These data suggest that epithelial CCN2 (CTGF) or TGF- $\beta$ act in a paracrine fashion to regulate stromal cell function. Similar conclusions were drawn from studies of TGF- $\beta$ protein localisation during the preimplantation period, which showed that ECM of the stroma actively accumulated TGF- $\beta 1$ that was synthesised in and secreted from the epithelium. ${ }^{44}$

$\mathrm{P}_{4}$ is an essential hormone in the establishment and maintenance of pregnancy, at least partly because it is required to sensitise stromal cells to differentiate in response to an embryonic or artificial stimulus and to maintain their differentiated state. Nonetheless, direct induction of gene expression by $\mathrm{P}_{4}$ is not widely documented, although some growth factors (such as heparin binding epidermal growth factor (HB-EGF), insulin-like growth factor type 1 (IGF-1), vascular endothelial growth factor (VEGF), tumour necrosis factor $\alpha$ (TNF- $\alpha$ ), and amphiregulin) and growth factor receptors or binding proteins (such as the EGF receptor, IGF binding protein 1, and the TNF- $\alpha$ receptor type 1 ) appear to be $\mathrm{P}_{4}$ dependent. ${ }^{32}$ Although detailed studies of the effects of $\mathrm{P}_{4}$ on TGF- $\beta$ are lacking in the literature, neither TGF- $\beta 2$ nor TGF- $\beta 3$ were reported to be significantly affected by $\mathrm{P}_{4}$ treatment. ${ }^{29}$ However, in our studies, a single injection of $\mathrm{P}_{4}$ was effective in stimulating the expression of ccn 2 (ctgf) and TGF- $\beta 1$ over control mice, but this response was less robust than that seen with $\mathrm{E}_{2}$. The $\mathrm{P}_{4}$ responsiveness of the $\operatorname{con} 2$ (ctgf) and TGF- $\beta$ genes may account, at least in part, for their high expression in the $\mathrm{P}_{4}$ dominated decualisation phase following implantation. ${ }^{14}$ While epithelial rather than stromal ccn2 (ctgf) mRNA was induced by $\mathrm{P}_{4}$, a similar pattern of regulation has been reported for other uterine genes including amphiregulin, a member of the EGF family, which is produced by epithelial cells in response to $\mathrm{P}_{4}{ }^{45}$ Although co-injection of $\mathrm{P}_{4}$ with $\mathrm{E}_{2}$ did not antagonise the transient $\mathrm{E}_{2}$ stimulated accumulation of TGF- $\beta 2 \mathrm{mRNA}$ in an earlier study, ${ }^{29} \mathrm{P}_{4}$ appeared to antagonise the $\mathrm{E}_{2}$ induced increase in TGF- $\beta 1$ and $\operatorname{con} 2$ (ctgf) expression by epithelial cells in our studies. Similar opposing effects between $\mathrm{E}_{2}$ and $\mathrm{P}_{4}$ on their effector molecules are not uncommon and have been documented previously for several uterine growth factors including HB$\mathrm{EGF}^{46}$ amphiregulin, ${ }^{45}$ and basic fibroblast growth factor. ${ }^{32}$

The similarity between CCN2 (CTGF) and TGF- $\beta$ in their patterns of expression and localisation are consistent with TGF- $\beta$ dependent mechanisms of ccn2 (ctgf) gene transcription, which could be both steroid dependent and independent. However, in several situations we found high amounts of TGF- $\beta$ protein in stromal cells but no detectable ccn2 (ctgf) mRNA. These findings may suggest that: (1) TGF- $\beta$ was present in its inactive latent form, (2) stromal cells were TGF- $\beta$ responsive but the $\operatorname{ccn} 2$ (ctgf) gene was refractory to the effect of TGF- $\beta$, and/or (3) functional TGF- $\beta$ receptors were not present on the stromal cells. However, this last possibility seems unlikely because of the previously reported presence of the type I and II TGF- $\beta$ receptors in stromal cells on days $1-3$ of pregnancy and of the type I, II, and III TGF- $\beta$ receptors in stromal cells on day 4 and the decidua thereafter. ${ }^{47}$

In conclusion, these and previous data demonstrate that maternal factors are principal cues for CCN2 (CTGF) production in the uterus because it is produced in cycling and pseudopregnant animals, its expression during pseudopregnancy is comparable to that seen in the preimplantation period, and its expression is regulated by ovarian steroids. Our studies further suggest that ccn2 (ctgf) gene transcription in the uterus is not only regulated by female sex steroids but also by TGF- $\beta 1$ 
dependent and independent mechanisms. Thus, CCN2 (CTGF) is likely to mediate at least some of the effects of steroid hormones and TGF- $\beta$ on endometrial function in cycling and pregnant animals.

This work was supported by USDA grant 9803693 .

1 Brigstock DR. The connective tissue growth factor/cysteine(CCN) family. Endocr Rev 1999;20:189-206.

2 Grotendorst GR. Connective tissue growth factor: a mediator of TGF-beta action on fibroblasts. Cytokine Growth Factor Rev 1997;8:171-9.

3 Lau LF, Lam SC. The CCN family of angiogenic regulators: the integrin connection. Exp Cell Res 1999;248. regulat 57 .

4 Moussad EE, Brigstock DR. Connective tissue growth factor: what's in a name? Mol Genet Metab 2000;71:27692.

5 Nakanishi T, Kimura Y, Tamura T, et al. Cloning of a mRNA preferentially expressed in chondrocytes by differential display-PCR from a human chondrocytic cell line that is identical with connective tissue growth factor (CTGF) mRNA. Biochem Biophys Res Commun 1997;234 206-10

6 Yang DH, Kim HS, Wilson EM, et al. Identification of glycosylated 38-kDa connective tissue growth factor (IGFBPrelated protein 2) and proteolytic fragments in human biological fluids, and up-regulation of IGFBP-rP2 expression by TGF-beta in Hs578T human breast cancer cells. 7 Clin Endocrinol Metab 1998;83:2593-6.

7 Boes M, Dake BL, Booth BA, et al. Connective tissue growth factor (IGFBP-rP2) expression and regulation in cultured bovine endothelial cells. Endocrinology 1999;140: cultured 1575 .

8 Hong HH, Uzel MI, Duan C, et al. Regulation of lysyl oxidase, collagen, and connective tissue growth factor by 1999;79:1655-67.

9 Riser BL, Denichilo M, Cortes P, et al. Regulation of connective tissue growth factor activity in cultured rat mesangial cells and its expression in experimental diabetic glomerulosclerosis. F Am Soc Nephrol 2000;11:25-38.

10 Wenger C, Ellenrieder V, Alber B, et al. Expression and differential regulation of connective tissue growth factor in pancreatic cancer cells. Oncogene 1999;18:1073-80.

11 Williams EJ, Gaca MD, Brigstock DR, et al. Increased expression of connective tissue growth factor in fibrotic human liver and in activated hepatic stellate cells. 7 Hepatol 2000;32:754-61.

12 Frazier K, Williams S, Kothapalli D, et al. Stimulation of fibroblast cell growth, matrix production, and granulation tissue formation by connective tissue growth factor. F Invest Dermatol 1996;107:404-11.

13 Kireeva ML, Latinkic BV, Kolesnikova TV, et al. Cyr61 and Fisp12 are both ECM-associated signaling molecules: activities, metabolism, and localization during developactivities, metabolism, and localization
ment. Exp Cell Res 1997;233:63-77.

14 Surveyor GA, Wilson AK, Brigstock DR. Localization of connective tissue growth factor during the period of embryo implantation in the mouse. Biol Reprod 1998;59 1207-13

15 Surveyor GA, Brigstock DR. Immunohistochemical localization of connective tissue growth factor (CTGF) in the mouse embryo between days 7.5 and 14.5 of gestation. Growth Factors 1999; 17:115-24.

16 Shimo T, Nakanishi T, Nishida T, et al. Connective tissue growth factor induces the proliferation, migration, and tube formation of vascular endothelial cells in vitro, and angiogenesis in vivo. 7 Biochem (Tokyo) 1999;126:137-45.

17 Nakanishi T, Takigawa M. Physiological function of connective tissue growth factor (CTGF/Hcs24) -its roles in the process of endochondral ossification. Seikagaku 1999;71:429-32.

18 Nakanishi $T$, Nishida $T$, Shimo $T$, et al. Effects of CTGF/Hcs24, a product of a hypertrophic chondrocyte-
specific gene, on the proliferation and differentiation of specific gene, on the proliferation and differentiation of
chondrocytes in culture. Endocrinology 2000;141:264-73.

19 Nishida T, Nakanishi T, Shimo T, et al. Demonstration of receptors specific for connective tissue growth factor on a human chondrocytic cell line (HCS-2/8). Biochem Biophys Res Commun 1998;247:905-9.

20 Nishida T, Nakanishi T, Asano $M$, et al. Effects of CTGF/Hcs24, a hypertrophic chondrocyte-specific gene product, on the proliferation and differentiation of osteoblastic cells in vitro. F Cell Physiol 2000;184:197-206.

21 Uzumcu M, Homsi MF, Ball DK, et al. Localization of connective tissue growth factor in human uterine tissues. Mol Hum Reprod 2000;6:1093-8.

22 Wandji SA, Gadsby JE, Barber JA, et al. Messenger ribonucleic acids for MAC25 and connective tissue growth factor (CTGF) are inversely regulated during folliculogenesis and early luteogenesis. Endocrinology 2000;141:2648-57.
23 Harding PA, Surveyor GA, Brigstock DR. Characterization of pig connective tissue growth factor (CTGF) cDNA, 1998;8:385-90.

24 Brigstock DR, Steffen CL, Kim GY, et al. Purification and characterization of novel heparin-binding growth factors in uterine secretory fluids. Identification as heparin-regulated $\mathrm{Mr} 10,000$ forms of connective tissue growth factor. F Biol Chem 1997;272:20275-82.

25 Brigstock DR. Purification and characterization of connective tissue growth factor (CTGF) using heparin-affinity chromatography. In: Aboul-Enein HY, ed. Analytical and preparative separation methods of biomacromolecules. New York: Marcel Dekker, 1999:397-414.

26 Ball DK, Surveyor GA, Diehl JR, et al. Characterization of 16- to 20-kilodalton ( $\mathrm{kDa}$ ) connective tissue growth factors (CTGFs) and demonstration of proteolytic activity for 38-kDa CTGF in pig uterine luminal flushings [published erratum appears in Biol Reprod 1998;59:1554]. Biol Reprod 1998;59:828-35.

27 Steffen CL, Ball-Mirth DK, Harding PA, et al. Characterization of cell-associated and soluble forms of connective tissue growth factor (CTGF) produced by fibroblast cells in vitro. Growth Factors 1998;15:199-213.

8 Ryseck RP, Macdonald-Bravo H, Mattei MG, et al. Structure, mapping, and expression of fisp-12, a growth factor-inducible gene encoding a secreted cysteine-rich protein. Cell Growth Differ 1991;2:225-33.

29 Das SK, Flanders KC, Andrews GK, et al. Expression of transforming growth factor-beta isoforms (beta 2 and beta 3) in the mouse uterus: analysis of the periimplantation period and effects of ovarian steroids. Endocrinology 1992;130:3459-66.

30 Takahashi T, Eitzman B, Bossert NL, et al. Transforming growth factors beta 1 , beta 2 , and beta 3 messenger RNA and protein expression in mouse uterus and vagina during estrogen-induced growth: a comparison to other estrogenregulated genes. Cell Growth Differ 1994;5:919-35.

31 Brigstock DR. Growth factors in the uterus: steroidal regulation and biological actions. Baillieres Clin Endocrinol Metab 1991;5:791-808.

32 Rider V, Piva M. Role of growth factors of uterine and fetalplacental origin during pregnancy. In: Bazer FW, ed. The endocrinology of pregnancy. New Jersey: Humana Press, 1997:83-124.

33 Brigstock DR, Heap RB, Brown KD. Polypeptide growth factors in uterine tissues and secretions. $\mathcal{F}$ Reprod Fertil 1989;85:747-58.

34 Pollard JW. Regulation of polypeptide growth factor synthesis and growth factor-related gene expression in the rat and mouse uterus before and after implantation. $\mathcal{F}$ Reprod Fertil 1990;88:721-31.

35 Psychoyos A. Uterine receptivity for nidation. Ann N Y Acad Sci 1986;476:36-42

36 Chang M. Development and fate of transferred rabbit ova or blastocyst in relation to the ovulation time of recipients. $\mathcal{F}$ Exp Zool 1950;114:197-225.

37 Betteridge KJ, Eaglesome MD, Randall GC, et al. Collection, description and transfer of embryos from cattle 10-16 days after oestrus. F Reprod Fertil 1980;59:205-16.

38 Bergh PA, Navot D. The impact of embryonic development and endometrial maturity on the timing of implantation. Fertil Steril 1992;58:537-42.

39 Simmen F, Simmen R, Bazer FW. Maternal growth factors as mediators of embryonic and neonatal growth. Biochem Soc Trans 1989; 17:587-9.

40 Rivera-Gonzalez R, Petersen DN, Tkalcevic G, et al. Estrogen-induced genes in the uterus of ovariectomized rats and their regulation by droloxifene and tamoxifen. $\mathcal{f}$ Steroid Biochem Mol Biol 1998;64:13-24.

41 Lee EH, Joo CK. Role of transforming growth factor-beta in transdifferentiation and fibrosis of lens epithelial cells. Invest Ophthalmol Vis Sci 1999;40:2025-32.

42 Frazier KS, Paredes A, Dube P, et al. Connective tissue growth factor expression in the rat remnant kidney model and association with tubular epithelial cells undergoing transdifferentiation. [In process citation.] Vet Pathol 2000; 37:328-35.

43 Hishikawa K, Oemar BS, Tanner FC, et al. Connective tissue growth factor induces apoptosis in human breast cancer cell line MCF-7. F Biol Chem 1999;274:37461-6.

44 Tamada $\mathrm{H}$, McMaster MT, Flanders KC, et al. Cell type-specific expression of transforming growth factor-beta 1 in the mouse uterus during the periimplantation period. Mol Endocrinol 1990;4:965-72.

45 Das SK, Chakraborty I, Paria BC, et al. Amphiregulin is an mplantation-specific and progesterone-regulated gene in the mouse uterus. Mol Endocrinol 1995;9:691-705.

46 Zhang Z, Funk C, Roy D, et al. Heparin-binding epidermal growth factor-like growth factor is differentially regulated by progesterone and estradiol in rat uterine epithelial and stromal cells. Endocrinology 1994;134:1089-94.

47 Das SK, Lim H, Wang J, et al. Inappropriate expression of human transforming growth factor (TGF)-alpha in the uterus of transgenic mouse causes downregulation of TGF-beta receptors and delays the blastocyst-attachment reaction. $\mathcal{F}$ Mol Endocrinol 1997;18:243-57. 